\title{
M-line TTN Mutations in Salih Myopathy: Novel Biallelic Mutation and Review of the Literature
}

\author{
Youssef El Kadiri ( $\nabla$ y1elkadiri@gmail.com ) \\ Ilham Ratbi \\ Faculté de Médecine et de Pharmacie, Mohammed V University in Rabat \\ Jaber Lyahyai \\ Faculté de Médecine et de Pharmacie, Mohammed V University in Rabat \\ Abdelaziz Sefiani \\ Faculté de Médecine et de Pharmacie, Mohammed V University in Rabat
}

Faculté de Médecine et de Pharmacie, Mohammed V University in Rabat https://orcid.org/0000-0002-6033-2395

\section{Research Article}

Keywords: Salih myopathy, TTN mutation, M-line titin exons, Clinical exome sequencing

Posted Date: August 4th, 2021

DOI: https://doi.org/10.21203/rs.3.rs-743096/v1

License: () (1) This work is licensed under a Creative Commons Attribution 4.0 International License. Read Full License 


\section{Abstract}

Background: Salih myopathy (SALMY), also known as early-onset myopathy with fatal cardiomyopathy (EOMFC) is a rare, heterogeneous, and severe form of titinopathies with autosomal recessive inherited neuromuscular disorders that affects both skeletal and cardiac muscles. It was previously identified only in the Arab population with unknown incidence. TTN mutations that have been reported in congenital myopathies are associated with a variety of phenotypic spectrum of titinopathies, which are scattered along the 364 exons of the gene. We report a Moroccan family with an affected patient diagnosed with Salih myopathy by next-generation sequencing (NGS) with a literature review of this rare entity.

Methods: Genetic investigation by NGS was performed in a consanguineous Moroccan female child aged 29 months with congenital myopathy. Sanger sequencing confirmation was performed on the patient and both of her parents. Clinical and molecular data of the patient were correlated with 14 patients reported in the literature for congenital myopathy associated with a heart defect or development of dilated cardiomyopathy with at least one mutation in the M-band titin protein as inclusion criteria.

Results: Bioinformatics analysis of Clinical Exome Sequencing (CES) data identified a novel homozygous truncating mutation c.106541delA p. (Asp35514Valfs*32) in exon 361 of the TTN gene. Sanger sequencing confirmed the mutation at a homozygous state in the proband and that both her parents are heterozygous carriers.

Conclusions: Application of next-generation sequencing in rare genetic heterogeneous forms as SALMY provides more evidently an increasing proportion of congenital myopathies than currently recognized and expands the mutation spectrum of the TTN gene for better guiding the genetic diagnosis with adequate genetic counseling to the Moroccan families.

\section{Background}

Early-onset myopathy with fatal cardiomyopathy (EOMFC), also known as Salih myopathy (SALMY; MIM \#611705), is a rare form of congenital titinopathies firstly described in two Arabic families in 2007 [1]. It is caused by homozygous or compound heterozygous mutations on a complex gene of 364 exons on 2q31 (GRCh37) coding for titin protein [2-4]. As one of the main sarcomere components, titin plays a crucial role in sarcomere assembly during myogenesis, maintains structural integrity, ensures muscle elasticity, and involves various cell signaling functions. It is expressed in both skeletal and cardiac muscles spanning the sarcomere from the Z-disk to the M-band $[2,5,6]$.

Mutations in the TTN gene have been associated with a broad range of genetic muscular disorders including cardiac and skeletal muscle diseases. Interestingly, all pathogenic autosomal recessive TTN mutations reported in EOMFC form have been shown in patients with both skeletal and cardiac muscle abnormalities [1,4]. Recently, congenital titinopathies with heart failure include several heterogeneous forms that vary in terms of age at onset of clinical signs of myopathy which may be at birth or infancy, the pattern of muscle involvement with or without dystrophic signs, and the age of onset of dilated cardiomyopathy $[4,7]$. EOMFC, in particular, is characterized by early-onset muscular weakness with slow progression in skeletal muscle followed by dilated cardiomyopathy in childhood with rapid progression [1].

Before the implementation of next-generation sequencing (NGS), routine molecular analysis of the whole TTN gene was a major challenge in research and diagnosis laboratories due to its huge size. The introduction of NGS technology has enabled the rapid and in-depth investigation of patients resulting in a consistent identification of rare and novel TTN mutations for a better assessment of titinopathies and genotype-phenotype correlation [8].

Herein, we report clinical and molecular findings of a severe form of Salih myopathy in a Moroccan patient who we identified by NGS a novel homozygous mutation in the TTN gene.

An accession number from the National Center for Biotechnology Information (NCBI) ClinVar database was retrieved for this novel TTN mutation. We also present a review of the literature of patients with congenital titinopathy and heart failure caused by mutations at least in the M-line titin exons.

\section{Patients And Methods}

\section{Clinical and paraclinical presentation of the proband}

A consanguineous Moroccan family with one affected child was referred to our Medical Genetic Center for genetic evaluation and molecular analysis. The female proband IV. 6 was 29 months of age at the time of her first genetic consultation. She was born of a healthy couple (III.3 and III.11) with a previous family history of congenital hypotonia noticed in her paternal cousin (IV.3) followed by sudden cardiac death by dilated cardiomyopathy at the age of 4 months without any genetic diagnosis (Fig. 1A). The proband (IV.6) showed congenital hypotonia with difficult suckling, and delayed motor milestones. She raised her head at 6 months and could sit with support at 8 months of age. She was able to stand with support until 14 months and acquired an unstable gait ambulant at the age of 18 months. Neuropediatrics evaluation reported pelvic girdle muscle weakness, absence of the deep tendon reflexes in the lower limbs, and positive Gowers' signs with relative calf hypertrophy. Facial muscles were also affected resulting in a lagophthalmos and a half-open mouth. Global motor development performances exhibited slow improvement.

Electromyogram (EMG) exam showed normal nerve conduction with a myogenic pattern in the upper and lower limbs. The serum creatine kinase (CK) was four times the upper normal level.

At the age of 27 months, electrocardiogram (ECG) and ultrasonic cardiogram (UCG) showed left ventricle reduced function with rhythm disturbances, which resulted in dilated cardiomyopathy (DCM) with a hypokinetic, enlarged, and spherical left ventricle without any abnormality in congenital mitral valve detected. 
Obstacles to aortic ejection, in particular, coarctation of the aorta and congenital anomalies of coronary arteries were absent. The Plasma carnitine level was normal.

\section{Molecular diagnosis strategy and consent}

Because of the phenotypic and genetic heterogeneity of congenital myopathies, we performed a Clinical Exome Sequencing (CES) for the patient. Informed consent was obtained from the proband's parents before initiation of a molecular genetic test.

\section{Genetic testing, bioinformatics analysis, and Sanger confirmation}

Peripheral blood was collected from the proband and her parents. Amplification of 4490 genes with known hereditary mutations associated with various diseases was carried out using Clinical Exome Solution v2 kit (SOPHiA Genetics, Boston, USA) on the Illumina NextSeq platform (Illumina Inc., San Diego, CA, USA). Raw data were analyzed, annotated, and filtered using SOPHiA ${ }^{\mathrm{TM}}$ DDM platform, V5.7.7 (SOPHiA Genetics, Boston, USA).

For the variant filtering process, the analysis focused on a virtual gene panel composed of 108 genes involved in many neuromuscular disorders. Variants in these genes were filtered by the following criteria: i) those with a minor allele frequency (MAF) greater than 0.01 in different public databases (1000 Genomes Project: http://www.internationalgenome.org/, gnomAD: http://gnomad.broadinstitute.org/ and ESP5400: http://evs.gs.washington.edu/), and greater than 0.02 in local resources (house database) were filtered out; ii) Only variants in accordance with the recessive mode of inheritance were retained; iii) variants predicted to be benign or tolerated by Polymorphism Phenotyping v2 (PolyPhen2, available at http://genetics.bwh.harvard.edu/pph2/), Sorting Intolerant From Tolerant (SIFT, available at http://sift.jcvi.org/) or MutationTaster (available at http://www.mutationtaster.org/) were filtered out. After the data were filtered, only one frameshift homozygous variant on the TTN gene was retained as a potential candidate variant (Fig. 2).

The TTN variant identified in the M-line TTN was confirmed by Sanger sequencing in the proband and her parents at our department of Medical Genetics in Rabat with the following primers: (TTN_ex361_F/ 5'-TTCCAAAAGTGGAACTGAGAAAG-3'; TTN_ex361_R/ 5'-TGATTTCCTCATGGACAATGG-3'). PCR products were electrophoresed on $1 \%$ agarose gel. Sanger sequencing was done with dye terminator chemistry (ABI Prism ${ }^{\circledR}$ BigDye v3.1 kit) and sequenced on an automated sequencer Applied Biosystems 3500 Genetic Analyzer. Obtained sequences were analyzed by Sequencing Analysis software version 7.0 (Applied Biosystems, Thermo Fisher).

The actual numbering of TTN exons (from exon 1 to exon 364) was done according to the LRG schema following the Human Genome Variation Society recommendations (http://varnomen.hgvs.org/) using the inferred complete TTN metatranscript (NM_001267550.2; LRG391_t1) as a reference which is recommended for clinical reporting and also adopted by the Leiden Open Variation Database v.3.0. The reported variant was cross-checked with the ClinVar (http://www.ncbi.nlm.nih.gov/clinvar/), LOVD database (https://databases.lovd.nl/shared/genes/TTN), Cardiodb mutation databases

(https://www.cardiodb.org/titin/), 1000 Genomes Project database (http://www.1000genomes.org/), gnomAD (https://gnomad.broadinstitute.org/), and with the Human Gene Mutation Database (HGMD Public site; (http://www.hgmd.cf.ac.uk/ac/gene.php?gene=TTN). (Accessed on April 1, 2021)

\section{Inclusion and exclusion criteria of the literature review}

In the present study, we have used the Human Gene Mutation Database (public version) (http://www.hgmd.cf.ac.uk) as a reference database and we have also searched in the National Library of Medicine's PubMed database (https://pubmed.ncbi.nlm.nih.gov/) for other reported series related to congenital titinopathies with heart disease caused by at least one mutation located in one of the last six exons of the C-terminal M-line (Fig. 3C).

We put as inclusion criteria all patients with congenital myopathy associated with a heart defect or development of DCM. We have completely excluded the same forms caused in some patients by outside M-band TTN mutations to highlight the importance of the C-terminal titin region and its major role involved in the sarcomere structure integrity, to make it in the short term as an emerging target biomarker for genetic researching of further phenotypes and to expand clinical spectrum to provide a more comprehensible correlation genotype-phenotype.

\section{Results}

In our case, the bioinformatics analysis from CES raw data through Sophia DDM platform revealed the appearance of 6894 variants through the sequencing of 4490 genes, all in which have a high-quality control. The total number of variants was reduced to a single pathogenic variant NM_001267550.2; LRG391_t1(TTN):c.106541delA p.(Asp35514Valfs*32) detected at homozygous state in exon 361 of TTN gene after the application of a virtual panel composed of genes involved in neuromuscular diseases, and the filters already mentioned above.

According to the Standards and guidelines, established by the ACMG and the Association for Molecular Pathology, for the interpretation of sequence variants, the variant c.106541delA was in line with the interpretation rule of "Pathogenic" including these criteria: PVS1, PM2, PP3, PP5 (Table 1).

Table 1

Criteria of ACMG classifications adopted for interpretation of our novel variant

\begin{tabular}{|c|c|c|}
\hline Rule & $\begin{array}{l}\text { Strength of } \\
\text { evidence }\end{array}$ & Explanation \\
\hline & & $\begin{array}{l}\text { The variant causes a frameshift with the creation of a premature stop codon in the gene where loss-of-function (LOF) due to the } \\
\text { synthesis of a truncated protein is a known mechanism of disease }\end{array}$ \\
\hline & & The variant is absent from controls and not found in gnomAD genomes \\
\hline & & Computational verdict based on one pathogenic prediction from phyloP vs no benign predictions \\
\hline & & ClinVar classifies this variant as Pathogenic (our submission on April 15,2021 ) \\
\hline
\end{tabular}


Abbreviations: PM, pathogenic moderate; PP, pathogenic supporting; PVS, pathogenic very strong.

The mutation led to the generation of reading out of frame with creation of a premature stop codon after 32 amino acids downstream of Aspartate amino acid located at position 35514Aa, predicting a truncated protein synthesis lacking the last $446 \mathrm{C}$-terminal titin amino acids residues.

A direct Sanger sequencing confirmed that the affected patient carried the mutation c. $106541 \mathrm{del}$ A in a homozygous state and both of her parents were heterozygous carriers. (Fig. 1B-D).

The accession number from ClinVar database, SCV001571326.1 (submitted: Apr 15, 2021), was assigned to our novel identified mutation.

Clinical and molecular data about EOMFC allowed us to retain this diagnostic in our patient based on the following criteria: i) her Moroccan origin, ii) biallelic TTN mutation located in M-band (Mex3), iii) combination of congenital myopathy signs with DCM excluding carnitine involvement in DCM development (normal value). All this indicated the similarity with EOMFC or Salih myopathy (SALMY) which is described as a rare form identified firstly in patients of Arab descent [9] and it is part of a large and heterogeneous form of AR MmD-HD.

The clinical characteristics and molecular findings of all 14 patients from 10 families reported in the literature in addition to our case are illustrated in Table 2. Muscle biopsy for electron microscopy analysis was not performed in our patient because is not available in Morocco. 
Table 2

Clinical and molecular data of patients with congenital titinopathy and heart failure caused by biallelic mutations which at least one in the M-line titin exo

\begin{tabular}{|c|c|c|c|c|c|c|c|c|c|c|}
\hline ID & Sex & origin & $\begin{array}{l}\text { Age of } \\
\text { onset }\end{array}$ & $\begin{array}{l}\text { Musculoskeletal } \\
\text { signs }\end{array}$ & $\begin{array}{l}\text { CK } \\
\text { level } \\
\text { (IU/L) }\end{array}$ & $\begin{array}{l}\text { Muscle } \\
\text { weakness } \\
\text { evolution }\end{array}$ & $\begin{array}{l}\text { Cardiac function } \\
\text { (Age at death) }\end{array}$ & $\begin{array}{l}\text { Mutation } \\
\text { (Allele1/Allele2) }\end{array}$ & Exon_region & Ref€ \\
\hline $1_{a}$ & M & Moroccan & \multirow[t]{3}{*}{ Infancy } & \multirow{3}{*}{$\begin{array}{l}\text { Delayed motor } \\
\text { milestones, } \\
\text { ambulant between } \\
20-24 \text { months, } \\
\text { muscle weakness } \\
\text { in lower limbs } \\
\text { (proximal and } \\
\text { distal) and facial } \\
\text { muscles, } \\
\text { asymmetric ptosis, } \\
\text { pseudohypertrophy } \\
\text { in lower limbs, } \\
\text { spinal rigidity, and } \\
\text { moderate joint and } \\
\text { neck contractures. } \\
\text { The patient 1c } \\
\text { developed } \\
\text { scoliosis after the } \\
\text { age of } 11 \text { years }\end{array}$} & \multirow[t]{5}{*}{$\begin{array}{l}1.5 \text { to } \\
7 \times N\end{array}$} & \multirow[t]{5}{*}{$\begin{array}{l}\text { Slow } \\
\text { progression }\end{array}$} & $\begin{array}{l}\text { DCM at } 12 \text { years } \\
\text { (17 years ) }\end{array}$ & \multirow[t]{3}{*}{$\begin{array}{l}\text { c.106571delA } \\
\text { (p.Lys35524Argfs*22) }\end{array}$} & \multirow[t]{3}{*}{$\begin{array}{l}361\left(360^{\neq}\right) \_M- \\
\text { band }\end{array}$} & \multirow[t]{3}{*}{$\begin{array}{l}\text { Carr } \\
\text { et al }\end{array}$} \\
\hline $1_{b}$ & M & Moroccan & & & & & $\begin{array}{l}\text { DCM at } 5 \text { years } \\
\text { (8 years ) }\end{array}$ & & & \\
\hline $1_{c}$ & M & Moroccan & & & & & $\begin{array}{l}\text { DCM at } 11 \text { years, } \\
\text { Heart } \\
\text { transplantation at } \\
15 \text { years } \\
\text { (17 years) }\end{array}$ & & & \\
\hline $2 a$ & M & Sudanese & \multirow[t]{2}{*}{ Birth } & \multirow{2}{*}{$\begin{array}{l}\text { Neonatal } \\
\text { hypotonia with } \\
\text { delayed motor } \\
\text { development. } \\
\text { Patients } 2 a \text { and } 2 b \\
\text { were ambulant at } \\
26 \text { months and } 4 \\
\text { years, respectively. } \\
\text { Generalized } \\
\text { muscle weakness } \\
\text { including facial } \\
\text { muscles, } \\
\text { asymmetric ptosis, } \\
\text { and relative calf } \\
\text { hypertrophy }\end{array}$} & & & $\begin{array}{l}\text { DCM at } 16 \text { years } \\
\text { (19.5 years ) }\end{array}$ & \multirow[t]{2}{*}{$\begin{array}{l}\text { c.105528_105535del } \\
\text { (p.GIn35175Hisfs*9) }\end{array}$} & \multirow[t]{2}{*}{$\begin{array}{l}359\left(358^{\neq}\right)_{-} \\
\text {M-band }\end{array}$} & \multirow[t]{2}{*}{$\begin{array}{l}\text { Carr } \\
\text { et al }\end{array}$} \\
\hline $2 b$ & M & Sudanese & & & & & $\begin{array}{l}\mathrm{DCM} \text { at }>12 \\
\text { years ( } 17.5 \text { years) }\end{array}$ & & & \\
\hline $3 a$ & M & Turkish & \multirow[t]{2}{*}{ Infancy } & \multirow{2}{*}{$\begin{array}{l}\text { From the age of } 2 \\
\text { years, these two } \\
\text { patients had a } \\
\text { weakness, } \\
\text { moderate to severe } \\
\text { elbow and ankle } \\
\text { contractures. The } \\
\text { motor } \\
\text { development was } \\
\text { normal. } \\
\text { Good ability to } \\
\text { walk }\end{array}$} & \multirow[t]{2}{*}{$4 \times N$} & \multirow[t]{2}{*}{$\begin{array}{l}\text { Slow } \\
\text { progression }\end{array}$} & DCM at 19 years & \multirow[t]{2}{*}{$\begin{array}{l}\text { c.106407_106408delTG } \\
\text { (p.Glu35470Argfs`11) }\end{array}$} & \multirow[t]{2}{*}{$\begin{array}{l}360\left(359^{\neq}\right) \_M- \\
\text { band }\end{array}$} & \multirow[t]{2}{*}{$\begin{array}{l}\text { Cha } \\
\text { et al }\end{array}$} \\
\hline $3_{b}$ & M & Turkish & & & & & $\begin{array}{l}\text { Normal } \\
\text { echocardiography } \\
\text { in the younger } \\
\text { brother at } 16 \\
\text { years }\end{array}$ & & & \\
\hline 4 & $\mathrm{~F}$ & Caucasian & Birth & $\begin{array}{l}\text { Neonatal } \\
\text { hypotonia, poor } \\
\text { suckling (NG tube), } \\
\text { delayed head } \\
\text { control, walked at } \\
2 \text { years, never run } \\
\text { or jumped. Severe } \\
\text { elbow and ankle } \\
\text { contractures from } \\
6 \text { years, severe } \\
\text { rigid spin. } \\
\text { Scoliosis was } \\
\text { developed at the } \\
\text { age of } 12 \text { years }\end{array}$ & ${ }^{2-5 x}$ & $\begin{array}{l}\text { Slow } \\
\text { progression }\end{array}$ & $\begin{array}{l}\text { Neonatal ASD. } \\
\text { DCM at } 16 \text { years }\end{array}$ & $\begin{array}{l}\text { c. } 102523 \mathrm{C}>\mathrm{T} \\
(\text { p.Arg34175*) } \\
\text { c. } 105832 \mathrm{C}>\mathrm{T} \\
\left(\text { p. } G \ln 35278^{*}\right)\end{array}$ & $\begin{array}{l}359\left(358^{\neq}\right) \\
\text {_M-band } \\
359\left(358^{\neq}\right)_{-} \\
\text {M-band }\end{array}$ & $\begin{array}{l}\text { Cha } \\
\text { et al }\end{array}$ \\
\hline 5 & M & Caucasian & Infancy & $\begin{array}{l}\text { Normal motor } \\
\text { development. From } \\
\text { the age of } 5 \text { years, } \\
\text { the patient had } \\
\text { difficulties to } \\
\text { climbing stairs, } \\
\text { mild ankle joint } \\
\text { contractures. Mild } \\
\text { rigid spine, } \\
\text { scoliosis, and } \\
\text { ptosis. } \\
\text { Good ability to } \\
\text { walk }\end{array}$ & 195 & stable & $\begin{array}{l}\text { ASD, VSD in the } \\
1 \text { st year. DCM at } \\
13 \text { years and } \\
\text { cardiac } \\
\text { transplant at } 14 \\
\text { years. }\end{array}$ & $\begin{array}{l}\text { c.66695T > A } \\
\text { (p.Val22232Glu) } \\
\text { c.102057delT } \\
\text { (p.Asn34020Thrfs*9) }\end{array}$ & $\begin{array}{l}317\left(316^{\ddagger}\right)_{-} A- \\
\text { band } \\
359\left(358^{\neq}\right)_{-} \\
\text {M-band }\end{array}$ & $\begin{array}{l}\text { Cha } \\
\text { et al }\end{array}$ \\
\hline
\end{tabular}




\begin{tabular}{|c|c|c|c|c|c|c|c|c|c|c|}
\hline ID & Sex & origin & $\begin{array}{l}\text { Age of } \\
\text { onset }\end{array}$ & $\begin{array}{l}\text { Musculoskeletal } \\
\text { signs }\end{array}$ & $\begin{array}{l}\text { CK } \\
\text { level } \\
(\mathrm{IU} / \mathrm{L})\end{array}$ & $\begin{array}{l}\text { Muscle } \\
\text { weakness } \\
\text { evolution }\end{array}$ & $\begin{array}{l}\text { Cardiac function } \\
\text { (Age at death) }\end{array}$ & $\begin{array}{l}\text { Mutation } \\
\text { (Allele1/Allele2) }\end{array}$ & Exon_region & Refє \\
\hline 6 & $\mathrm{~F}$ & Caucasian & Birth & $\begin{array}{l}\text { Prenatal hypotonia } \\
\text { (decreased fetal } \\
\text { movements), } \\
\text { severe motor skill } \\
\text { delay, scoliosis } \\
\text { from birth. She } \\
\text { was sitting and } \\
\text { standing with } \\
\text { support at the age } \\
\text { of } 19 \text { months and } \\
\text { she was never } \\
\text { walked }\end{array}$ & NA & stable & $\begin{array}{l}\text { DCM at the age } \\
\text { of } 1 \text { month and } \\
\text { cardiac } \\
\text { transplant at } 4 \\
\text { years }\end{array}$ & $\begin{array}{l}\text { c. } 9163+1 G>C \text { (p.?) } \\
\text { c. } 102214 T>C \\
\text { (p. } \text { Trp34072Arg) }\end{array}$ & $\begin{array}{l}\text { Intron 38-39_ } \\
\text { l-band } \\
359\left(358^{\neq}\right)_{-} \\
\text {M-band }\end{array}$ & $\begin{array}{l}\text { Cha } \\
\text { et al }\end{array}$ \\
\hline 7 & M & Italian & Birth & $\begin{array}{l}\text { Delayed motor } \\
\text { milestones with } \\
\text { general weakness. } \\
\text { At the age of } 8 \\
\text { years, he was able } \\
\text { to walk } \\
\text { independently, } \\
\text { presented scoliosis } \\
\text { and ankle } \\
\text { contractures }\end{array}$ & NA & $\begin{array}{l}\text { Slow } \\
\text { progression }\end{array}$ & $\begin{array}{l}\text { DCM at } 8 \text { years } \\
\text { and cardiac } \\
\text { transplant at } 11 \\
\text { years }\end{array}$ & $\begin{array}{l}\text { c.9577C> T } \\
(\text { p. Arg3193*) } \\
\text { c. } 105832 C>T \\
(\text { p.GIn35278*) }\end{array}$ & $\begin{array}{l}\text { 41_ I-Band } \\
359\left(358^{\neq}\right) \text {_M- } \\
\text { band }\end{array}$ & $\begin{array}{l}\text { Fatt } \\
\text { al. } 2\end{array}$ \\
\hline 8 & M & Chinese & Infancy & $\begin{array}{l}\text { Delayed early } \\
\text { motor } \\
\text { development, } \\
\text { difficulty in } \\
\text { sucking. } \\
\text { Proximal limb } \\
\text { muscle weakness, } \\
\text { a rigid spine, high- } \\
\text { arched palate, and } \\
\text { contracture of the } \\
\text { Achilles tendon. }\end{array}$ & $\begin{array}{l}2- \\
15 \times N\end{array}$ & NA & $\begin{array}{l}\text { Congenital atrial } \\
\text { septal aneurysm }\end{array}$ & $\begin{array}{l}\text { c.3880_3884delGATTC } \\
\text { (p.Asp1294Lysfs*6) } \\
\text { c.105800_105801delCA } \\
\text { (p.Thr35267Argfs*31) }\end{array}$ & $\begin{array}{l}\text { 23_near Z-disk } \\
359\left(358^{\neq}\right) \text {_M- } \\
\text { band }\end{array}$ & $\begin{array}{l}\text { Yu } \epsilon \\
2011\end{array}$ \\
\hline 9 & $\mathrm{~F}$ & Finnish & Birth & $\begin{array}{l}\text { Severe hypotonia } \\
\text { with general } \\
\text { muscle weakness. }\end{array}$ & NA & $\begin{array}{l}\text { Slow } \\
\text { progression }\end{array}$ & DCM & $\begin{array}{l}\text { c.105186dup p. } \\
\text { (Ala35063Cysfs*6) }\end{array}$ & $\begin{array}{l}359\left(358^{\neq}\right) \text {-M- } \\
\text { band }\end{array}$ & $\begin{array}{l}\text { Savi } \\
\text { et al }\end{array}$ \\
\hline 10 & M & Italian & Birth & $\begin{array}{l}\text { Delayed motor } \\
\text { milestones with } \\
\text { general muscle } \\
\text { weakness }\end{array}$ & NA & $\begin{array}{l}\text { Slow } \\
\text { progression }\end{array}$ & $\begin{array}{l}\text { right axial } \\
\text { deviation showed } \\
\text { at } 3 \text { years }\end{array}$ & $\begin{array}{l}\text { c. } 914+1 G>C(p . ?) \\
\text { c. } 105832 C>T p . \\
\left(G \ln 35278^{\star}\right)\end{array}$ & $\begin{array}{l}\text { Intron 6-7_Z- } \\
\text { disk } \\
359\left(358^{\neq}\right) \_M- \\
\text { band }\end{array}$ & $\begin{array}{l}\text { Savi } \\
\text { et al }\end{array}$ \\
\hline 11 & $\mathrm{~F}$ & Moroccan & Birth & $\begin{array}{l}\text { Congenital } \\
\text { hypotonia with } \\
\text { delayed motor } \\
\text { milestones. The } \\
\text { patient had pelvic } \\
\text { girdle muscle } \\
\text { weakness and } \\
\text { positive Gowers' } \\
\text { signs. Facial } \\
\text { muscle weakness } \\
\text { with } \\
\text { lagophthalmos } \\
\text { and half-open } \\
\text { mouth. and } \\
\text { acquired an } \\
\text { unstable gait } \\
\text { ambulant at the } \\
\text { age of } 18 \text { months }\end{array}$ & $4 \times N$ & $\begin{array}{l}\text { Slow } \\
\text { progression }\end{array}$ & $\begin{array}{l}\text { DCM at } 27 \\
\text { months }\end{array}$ & $\begin{array}{l}\text { c.106541delA } \\
\text { (p.Asp35514Valfs*32) }\end{array}$ & $\begin{array}{l}361\left(360^{\neq}\right)_{-} \\
\text {M-band }\end{array}$ & $\begin{array}{l}\text { Nov: } \\
\text { stud }\end{array}$ \\
\hline
\end{tabular}

Abbreviations: ASD, atrial septal defect; DCM, dilated cardiomyopathy; F, female; M, male; N, normal value; NA, not available; NG, nasogastric; VSD, ventricular septal defect.

Mutations were reported according to the meta-transcript (NM_001267550.2). Numbered of TTNexons was according to the HGVS recommendations, to the current Leiden database (LOVD) numbering (modified on $11^{\text {th }}$ October 2013), and to the cardiodb. TTN exon number used in this study was according to the LRG numbering. " Exon number according to the old numbering (before $11^{\text {th }}$ October 2013).

\section{Discussion}

Congenital titinopathy is a particular form of autosomal recessive titinonopathies including a large group of heterogeneous diseases like EOMFC, centronuclear myopathy, core myopathy with heart diseases, arthrogryposis multiplex congenita with myopathy. They are manifested in patients with prenatal 
or infant-onset forms of titinopathy associated with or without cardiac involvement and heterogeneous histopathological patterns. It is caused mainly by pathogenic recessive truncated TTN mutations as nonsense, frameshift, and splicing variants $[3,6,10]$.

To date, clinicians found it difficult to appropriately determine the adequate genetic test to the clinical features and are still unable to clinically distinguish congenital titinopathies from congenital myopathies related to other genes with or without heart disease [11]. Fortunately, recent technological progress improves our understanding of titin function and structural organization in the striated muscle sarcomeres despite its massive size and the complexity of their pathophysiological mechanisms linked to the TTN gene. Besides, it makes genetic diagnosis very easy and allows the sequencing of the entire TTN coding exons and identification of disorder-causing variants in patients with heterogeneous clinical features [4, 12].

As one of the main sarcomere components, titin comprises four main regions: an amino-terminal Z-disk, two middles I-band and A-band regions, and a Cterminal part spanning the M-band region (Fig. 3A, B). The TTN gene generates numerous alternative splicing variants resulting in seven titin transcripts of different lengths, with variable expression in skeletal and cardiac muscles $[13,14]$. Indeed, the diversity of titin isoforms are based on the presence of the N2A and N2B elements in the l-band region: The longest human theoretical isoform produces a predicted protein of 35991 amino acids (3 $960 \mathrm{kDa}$ ), N2BA and $\mathrm{N} 2 \mathrm{~B}$ encode the major cardiac muscle isoforms, N2A is the predominant titin isoform in skeletal muscle, Novex 1 encodes the minor cardiac muscle isoform; Novex 2 encodes the minor cardiac and skeletal muscle isoforms, and Novex 3 founds in all striated muscle. The M-band region of titin encodes by all of these isoforms $[4,15]$.

In this study, the affected patient had undergone a molecular genetic investigation using CES to carry out a wide-field screening of all genes involved in neuromuscular disorders, particularly those that are known for their pathogenicity in the development of skeletal and cardiac muscle forms. CES data analysis showed a recessive truncated mutation in the TTN gene. The c.106541delA mutation located in exon 361 of the M-band region in C-terminal was responsible for causing the clinical features in the patient. She had developed a congenital myopathy with delayed motor milestones associated to dilated cardiomyopathy at the age of 27 months.

Her clinical features are nearly similar to other reported studies in the literature. Carmignac and colleagues noticed firstly in two consanguineous families of Moroccan and Sudanese origin a novel EOMFC phenotype in 5 patients with skeletal muscle dysfunction appearing at birth or in infancy with generalized and slow progression of muscle weakness. In contrast, a dramatically progressive dilated cardiomyopathy developed in all the patients from the ages of 5 to 16 years, leading to death between 3 and 5 years after its diagnosis. Molecular analysis found a homozygous mutation for a one-base deletion on exon 361 (Mex3: c.106571delA, p.Lys35524Argfs`22) and an 8bp deletion near to the 3'-end of exon 359 (Mex1: c.105528_105535delAGTGACCA, p.GIn35176Hisfs*9) in Moroccan and Sudanese families, respectively [1]. Several studies demonstrated that the generation of truncated proteins in the M-band region led to sarcomere disorganization and the disruption of the M-band protein complex [16-19].

The clinical diagnosis and molecular characterization of additional families recruited by Chauveau et al. allowed them to suggest the term "Autosomal Recessive Multi-minicore Disease with Heart Disease" (AR MmD-HD) for all patients that have in common contractile skeletal muscle phenotype, a muscle biopsy was consistent with multi minicore lesions (central nuclei, type 1 fiber predominance, foci of mitochondria depletion...), and genetic conditions including a large and various clinical spectrum spanning from an Emery Dreifuss-like myopathy to a severe congenital myopathy with neonatal cardiac failure passing by EOMFC form. The six last exons of M-band represent $6.5 \%$ of the $T T N$ gene and the mutations harbored at least in one allele of these exons were significantly caused multi minicore congenital myopathy with primary heart disease [7].

Proceeding from the above, variants that have been already reported in the literature in the C-terminal part of the TTN gene allow the researchers to deduce a genotype-phenotype correlation even with limited extension. For instance, autosomal recessive truncating mutations detected in the first four $\mathrm{M}$-line exons (Mex1-4 or exons 359-362) cause a broad range of severe congenital or very early-onset muscle diseases with or without cardiomyopathy [1, 7, 11, 20, 21]. Moreover, a hypothesize shows a relationship between the position of truncated protein into the last six TTN exons (exons 359-364 or Mex1-Mex6) and the age of onset of the myopathy with a difference in clinical severity (exceptions are expected) [10].

A previously experimental study performed in a mouse model described that biallelic selective excision of titin exons Mex 1 and Mex2 lead to the expression of a titin protein devoid of the titin kinase (TK) domain, which was encoded by Mex1, results in embryonic lethality at mid-gestation [22-24] which suggests that this domain plays a key role in sarcomere integrity during myofibrillogenesis and allows the control of muscle gene expression [23, 25, 26].

Indeed, for more comprehension of M-line deficient titin in humans, Chauveau et al. previously reported two unrelated patients each carrying one heterozygous Mex1 mutation that affected the critical TK domain and was combined with another mutation outside the M-band in the second allele. The first patient carried the frameshift c.102057delT (p.Asn34020Thrfs*9) mutation at the beginning of the TK encoding sequence with the missense c.66695T >A ( .Val22232Glu) mutation in the exon 317. He had presented signs of heart dysfunction from birth and DCM at 13 years. In contrast, the second patient who carried the missense c.102214T > C (p.Trp34072Arg) mutation, affecting a highly conserved residue of the TK, together with another c.9163 + 1G > C mutation in the splice donor site at 5' of intron 38-39, developed a severe antenatal skeletal muscle hypotonia with neonatal cardiac failure. She developed a DCM at birth and performed a cardiac transplant at 4 years of age. Ex vivo and in vitro analysis showed a complete loss of functional human TK domain in this female patient [7].

In the same context, Fernandez-Marmiesse et al. reported a homozygous truncating mutation c.38661_38665delGAAAA (p.Lys12887Asnfs*6) in exon 198 (published as exon 197) in a newborn with arthrogryposis multiplex congenita associated with severe antenatal hypotonia without cardiac abnormality. The reason why some patients developed cardiomyopathy associated with skeletal muscle alteration and others without heart abnormalities remained ambiguous and their clinical interpretation is representing a great challenge [15]. 
Therefore, there is no definite correlation between the size of the truncated fragment and the involvement of the cardiac phenotype associated with skeletal muscle failure but there is a relation between the severity and the age of onset of skeletal muscle phenotype in the case of devoid TK functional.

Western blot (WB) analysis revealed that homozygous mutations cause premature stop codon in the M-band escarped from degradation through nonsensemediated mRNA decay (NMD) mechanism due to synthesis of near full-length titin $[4,10]$. On the contrary, the premature stop codons created upstream of Cterminal titin part were results by a lower amount of mutated transcript expression suggesting incomplete NMD [27]. However, in other studies, TTN truncated mutations detected at compound heterozygous state have an effect on the reduction of the expression level of one mutated allele, probably due to mRNA degradation or by post-translational degradation of titin protein [27-29]. Interestingly, the total absence of titin protein is most probably incompatible with life $[22,30]$.

An incomprehensible observation in this study was the absence of clinical phenotype (neither neuromuscular nor cardiac abnormalities) in both parents (aged 30 and 26 years) although they are heterozygous carriers of the novel mutation located in Mex3. It still unclear why heterozygous amino acid changes caused by M-line mutations lead in some adult patients to the appearance of phenotypes that are linked exclusively to skeletal muscle disorders like late-onset tibial muscular dystrophy (TMD) and in others with no alteration. Indeed, the hypotheses to explain this particular issue could be that for asymptomatic heterozygous parents of individuals with Salih myopathy, there is a degradation of the mutated mRNA through the NMD mechanism or that there is no support of the dominant-negative effect of this mutation in M-line [1].

\section{Conclusion}

Until recently, there is a limited amount but a wide range of phenotypes of congenital disease-causing TTN mutations combined with primary heart disease exhibited in M-line exons that were identified relatively in a few patients, which have undergone a full TTN analysis with a low frequency of cases. In addition, there is a critical challenge for the interpretation of the pathogenic impact of TTN missense variations that are often underestimated and probably underrepresented in the literature. Therefore, phenotype-genotype correlations are often unclear.

However, the introduction of NGS technology will provide an increasing number of TTN mutations in patients by sequencing the entire gene and will help expand the spectrum of titinopathies by paving the way for genetic diagnosis in affected families, in order to provide accurate genetic counseling. In this study, we assume that our patient belongs to the second Moroccan family who has supported molecular diagnosis with Salih myopathy in the literature. This novel mutation reported here will expand the mutational spectrum of the TTN gene especially in M-line titin exons.

\section{Abbreviations}

ACMG: American College of Medical Genetics and Genomics

AR MmD-HD: Autosomal Recessive Multi-minicore Disease with Heart Disease

CES: Clinical Exome Sequencing

CK: Creatine Kinase

DCM: Dilated Cardiomyopathy

ECG: Electrocardiogram

EMG: Electromyogram

EOMFC: Early-Onset Myopathy with Fatal Cardiomyopathy

MAF: Minor Allele Frequencies

NCBI: National Center for Biotechnology Information

NGS: Next-Generation Sequencing

NMD: Nonsense -mediated mRNA Decay

SALMY: Salih myopathy

TK: Titin Kinase

UCG: Ultrasonic Cardiogram

\section{Declarations}

\section{Ethics approval and consent to participate}

All genetic testing in this study were performed after consent from the parents of the proband in accordance with the tenets of the Declaration of Helsinki. 


\section{Consent for publication}

Written consent has been obtained from the proband's parents for publication of clinical details, radiological and biological data.

\section{Availability of data and materials}

The principal data generated and/or analyzed during the current study are included in the published article. The datasets used in this study are available from the corresponding author on reasonable request.

\section{Competing Interests}

The authors declare that they have no financial or other conflicts of interest.

\section{Funding}

This research did not receive any specific grant from funding agencies in the public, commercial, or not-for-profit sectors.

\section{Authors' contributions}

YEK: collected the genetic and molecular data, literature search in databases, analyzed and interpreted NGS raw data, performed the molecular study by Sanger sequencing, prepared the figures, and wrote the original draft. IR: performed the clinical genetic diagnosis and edited the manuscript with critical revision. JL: performed bioinformatics analysis, revised the manuscript, and contributed to the design of study. AS: performed the clinical genetic diagnosis, conceptualized and supervised the study, and revised the final manuscript. All authors read and approved the final manuscript.

\section{Acknowledgments}

We thank the family for their participation in this study.

Y. EL KADIRI was supported by the excellence research grant from the National Center for Scientific and Technical Research (CNRST), Rabat, Morocco.

\section{References}

1. Carmignac V, Salih MA, Quijano-Roy S, Marchand S, Al Rayess MM, Mukhtar MM, Urtizberea JA, Labeit S, Guicheney P, Leturcq F, et al: C-terminal titin deletions cause a novel early-onset myopathy with fatal cardiomyopathy. Ann Neurol. 2007;61:340-351.

2. Bang ML, Centner T, Fornoff F, Geach AJ, Gotthardt M, McNabb M, Witt CC, Labeit D, Gregorio CC, Granzier H, Labeit S: The complete gene sequence of titin, expression of an unusual approximately 700-kDa titin isoform, and its interaction with obscurin identify a novel Z-line to I-band linking system. Circ Res. 2001;89:1065-1072.

3. Chauveau C, Rowell J, Ferreiro A: A rising titan: TTN review and mutation update. Hum Mutat. 2014;35:1046-1059.

4. Savarese M, Sarparanta J, Vihola A, Udd B, Hackman P: Increasing Role of Titin Mutations in Neuromuscular Disorders. J Neuromuscul Dis. 2016;3:293308.

5. LeWinter MM, Granzier HL: Titin is a major human disease gene. Circulation. 2013;127:938-944.

6. Oates EC, Jones KJ, Donkervoort S, Charlton A, Brammah S, Smith JE, 3rd, Ware JS, Yau KS, Swanson LC, Whiffin N, et al: Congenital Titinopathy: Comprehensive characterization and pathogenic insights. Ann Neurol. 2018;83:1105-1124.

7. Chauveau C, Bonnemann CG, Julien C, Kho AL, Marks H, Talim B, Maury P, Arne-Bes MC, Uro-Coste E, Alexandrovich A, et al: Recessive TTN truncating mutations define novel forms of core myopathy with heart disease. Hum Mol Genet. 2014;23:980-991.

8. Biesecker LG, Green RC: Diagnostic clinical genome and exome sequencing. N Engl J Med. 2014;370:2418-2425.

9. Hackman P SM, Carmignac V, Udd B, Salih MA: Salih Myopathy. 12 Jan 2012 [updated 11 Apr 2019]. In: Adam MP, Ardinger HH, Pagon RA, Wallace SE, Bean LJH, Mirzaa G, Amemiya A, editors. GeneReviews [Internet]. Seattle (WA): University of Washington, Seattle;1993-2021.

10. Savarese M, Vihola A, Oates EC, Barresi R, Fiorillo C, Tasca G, Jokela M, Sarkozy A, Luo S, Diaz-Manera J, et al: Genotype-phenotype correlations in recessive titinopathies. Genet Med. 2020;22:2029-2040.

11. Ceyhan-Birsoy O, Agrawal PB, Hidalgo C, Schmitz-Abe K, DeChene ET, Swanson LC, Soemedi R, Vasli N, lannaccone ST, Shieh PB, et al: Recessive truncating titin gene, TTN, mutations presenting as centronuclear myopathy. Neurology. 2013;81:1205-1214.

12. Hackman P, Udd B, Bonnemann CG, Ferreiro A, Titinopathy Database C: 219th ENMC International Workshop Titinopathies International database of titin mutations and phenotypes, Heemskerk, The Netherlands, 29 April-1 May 2016. Neuromuscul Disord. 2017;27:396-407.

13. Labeit S, Lahmers S, Burkart C, Fong C, McNabb M, Witt S, Witt C, Labeit D, Granzier H: Expression of distinct classes of titin isoforms in striated and smooth muscles by alternative splicing, and their conserved interaction with filamins. J Mol Biol. 2006;362:664-681.

14. Guo W, Bharmal SJ, Esbona K, Greaser ML: Titin diversity-alternative splicing gone wild. J Biomed Biotechnol. 2010;2010:753675.

15. Fernandez-Marmiesse A, Carrascosa-Romero MC, Alfaro Ponce B, Nascimento A, Ortez C, Romero N, Palacios L, Jimenez-Mallebrera C, Jou C, Gouveia S, Couce ML: Homozygous truncating mutation in prenatally expressed skeletal isoform of TTN gene results in arthrogryposis multiplex congenita and myopathy without cardiac involvement. Neuromuscul Disord. 2017;27:188-192.

16. Hackman P, Vihola A, Haravuori H, Marchand S, Sarparanta J, De Seze J, Labeit S, Witt C, Peltonen L, Richard I, Udd B: Tibial muscular dystrophy is a titinopathy caused by mutations in TTN, the gene encoding the giant skeletal-muscle protein titin. Am J Hum Genet. 2002;71:492-500. 
17. Wang SM, Lo MC, Shang C, Kao SC, Tseng YZ: Role of M-line proteins in sarcomeric titin assembly during cardiac myofibrillogenesis. J Cell Biochem. 1998;71:82-95.

18. Fukuzawa A, Lange S, Holt M, Vihola A, Carmignac V, Ferreiro A, Udd B, Gautel M: Interactions with titin and myomesin target obscurin and obscurin-like 1 to the M-band: implications for hereditary myopathies. J Cell Sci. 2008;121:1841-1851.

19. Ge L, Fu X, Zhang W, Wang D, Wang Z, Yuan Y, Nonaka I, Xiong H: Recessive mutations in proximal I-band of TTN gene cause severe congenital multiminicore disease without cardiac involvement. Neuromuscul Disord. 2019;29:350-357.

20. Fattori F, Maggi L, Bruno C, Cassandrini D, Codemo V, Catteruccia M, Tasca G, Berardinelli A, Magri F, Pane M, et al: Centronuclear myopathies: genotypephenotype correlation and frequency of defined genetic forms in an Italian cohort. J Neurol. 2015;262:1728-1740.

21. Yu M, Zhu Y, Xie Z, Zheng Y, Xiao J, Zhang W, Nishino I, Yuan Y, Wang Z: Novel TTN mutations and muscle imaging characteristics in congenital titinopathy. Ann Clin Transl Neurol. 2019;6:1311-1318.

22. Weinert S, Bergmann N, Luo X, Erdmann B, Gotthardt M: M line-deficient titin causes cardiac lethality through impaired maturation of the sarcomere. J Cell Biol. 2006;173:559-570.

23. Gotthardt M, Hammer RE, Hubner N, Monti J, Witt CC, McNabb M, Richardson JA, Granzier H, Labeit S, Herz J: Conditional expression of mutant M-line titins results in cardiomyopathy with altered sarcomere structure. J Biol Chem. 2003;278:6059-6065.

24. Peng J, Raddatz K, Labeit S, Granzier H, Gotthardt M: Muscle atrophy in titin M-line deficient mice. J Muscle Res Cell Motil. 2005;26:381-388.

25. Mayans O, van der Ven PF, Wilm M, Mues A, Young P, Furst DO, Wilmanns M, Gautel M: Structural basis for activation of the titin kinase domain during myofibrillogenesis. Nature. 1998;395:863-869.

26. Lange S, Xiang F, Yakovenko A, Vihola A, Hackman P, Rostkova E, Kristensen J, Brandmeier B, Franzen G, Hedberg B, et al: The kinase domain of titin controls muscle gene expression and protein turnover. Science. 2005;308:1599-1603.

27. Perrin A, Metay C, Villanova M, Carlier RY, Pegoraro E, Juntas Morales R, Stojkovic T, Richard I, Richard P, Romero NB, et al: A new congenital multicore titinopathy associated with fast myosin heavy chain deficiency. Ann Clin Transl Neurol. 2020;7:846-854.

28. Perrin A, Juntas Morales R, Rivier F, Cances C, Walther-Louvier U, Van Goethem C, Theze C, Lacourt D, Pegeot H, Zenagui R, et al: The importance of an integrated genotype-phenotype strategy to unravel the molecular bases of titinopathies. Neuromuscul Disord. 2020;30:877-887.

29. Kellermayer D, Smith JE, 3rd, Granzier H: Titin mutations and muscle disease. Pflugers Arch. 2019;471:673-682.

30. Gerull B, Gramlich M, Atherton J, McNabb M, Trombitas K, Sasse-Klaassen S, Seidman JG, Seidman C, Granzier H, Labeit S, et al: Mutations of TTN, encoding the giant muscle filament titin, cause familial dilated cardiomyopathy. Nat Genet. 2002;30:201-204.

\section{Figures}

A

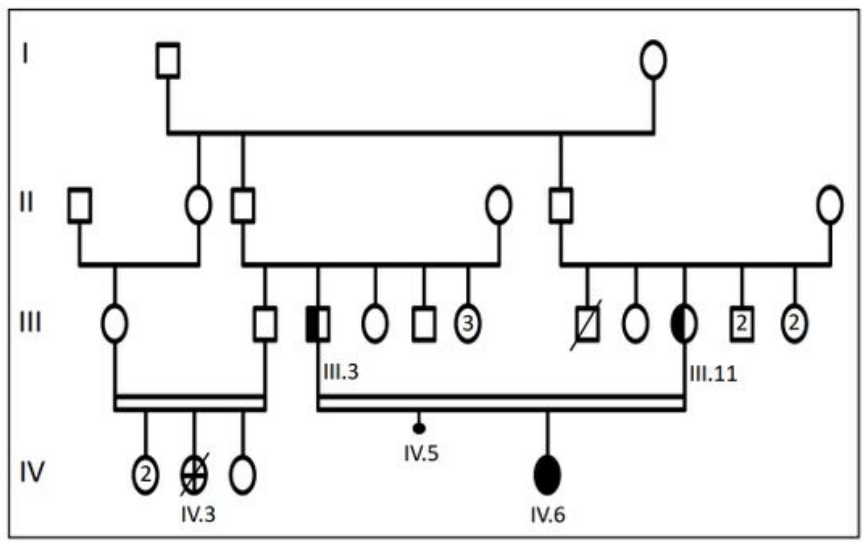

$\begin{array}{llllllllllllllllllll}G & C & P & A & : & A & A & A & A & G & A & 1 & A & C & : & 0 & A & G & 0\end{array}$

Normal

control
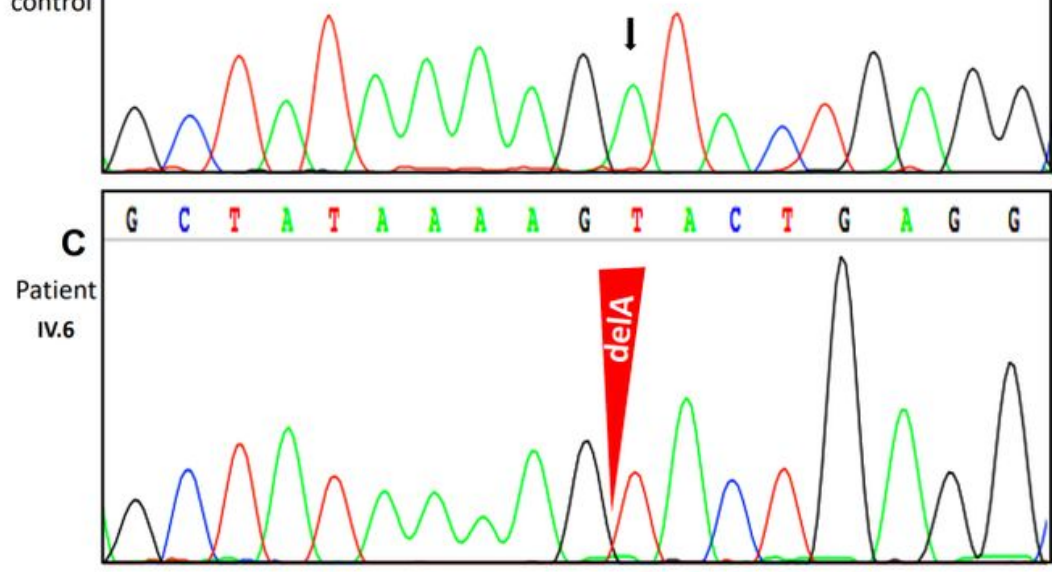

D

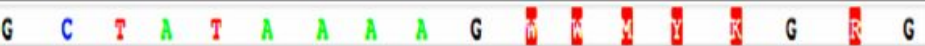

Parents III.3 and III.11

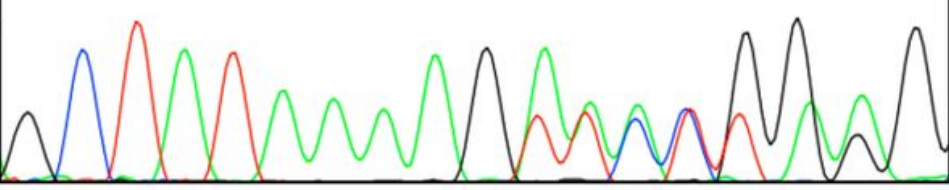

Figure 1

Page 10/12 
Pedigree of the Moroccan family and Sanger sequences of the identified TTN mutation A Pedigree of the studied family. The filled symbol represents the female child (proband) and open symbols represent unaffected individuals. The half-filled symbols identify heterozygote unaffected carriers shown in both of her parents. The paternal cousin of the proband (IV.3) had died of dilated cardiomyopathy without any genetic diagnosis. B Electropherogram in the control individual showing normal reference sequence (wild-type). C Electropherogram showing the homozygous mutation in the proband. D Electropherogram showing the heterozygous mutation in both of her parents with overlapping sequence from the mutation at position 106541 of cDNA. The black arrow indicates the position of the deletion.

\section{Bioinformatics filters}

Total variants with high QS detected in 4490 genes

Analysis of a virtual neuromuscular panel of 108 genes

$\downarrow$

Variants with MAF $<0,01$ in gnomAD, 1000 Genomes, ESP5400 public databases

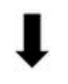

Variants with $\mathrm{MAF}<0,02$ in house database

Variants in accordance with the recessive mode of inheritance

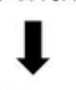

Variants predicted to be pathogenic or damaging by PolyPhen2, SIFT and MutationTaster

\section{Number of variants}

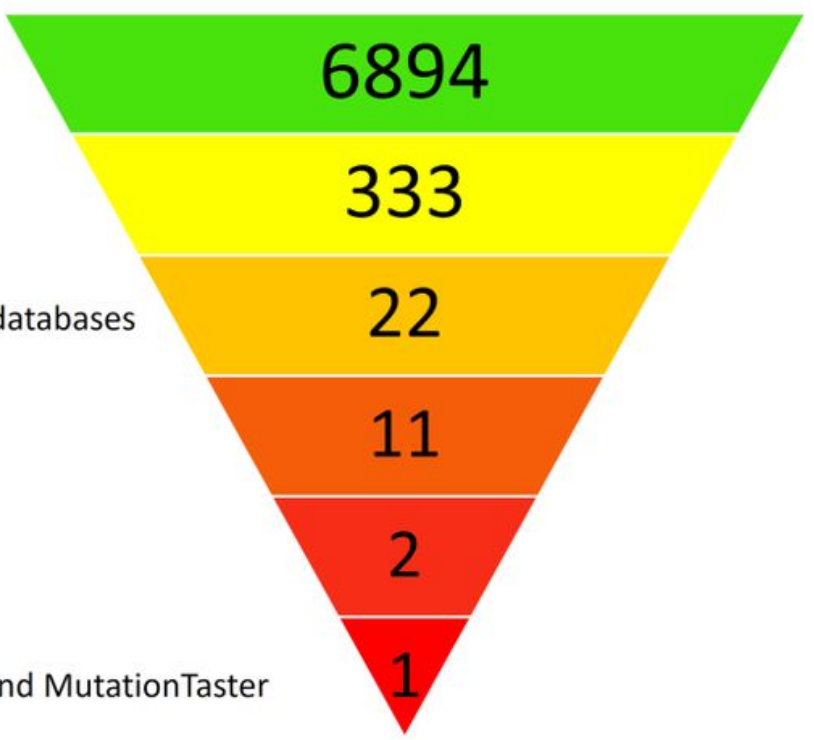

Figure 2

Overview of filtering variant strategy Bioinformatics filters used are listed on the left, and the number of variants that correspond to each analysis step is shown on the right. ESP: Exome Sequencing Project; MAF: Minor Allele Frequency; PolyPhen2: Polymorphism Phenotyping v2; QS: Quality score; SIFT: Sort Intolerant from Tolerant. 


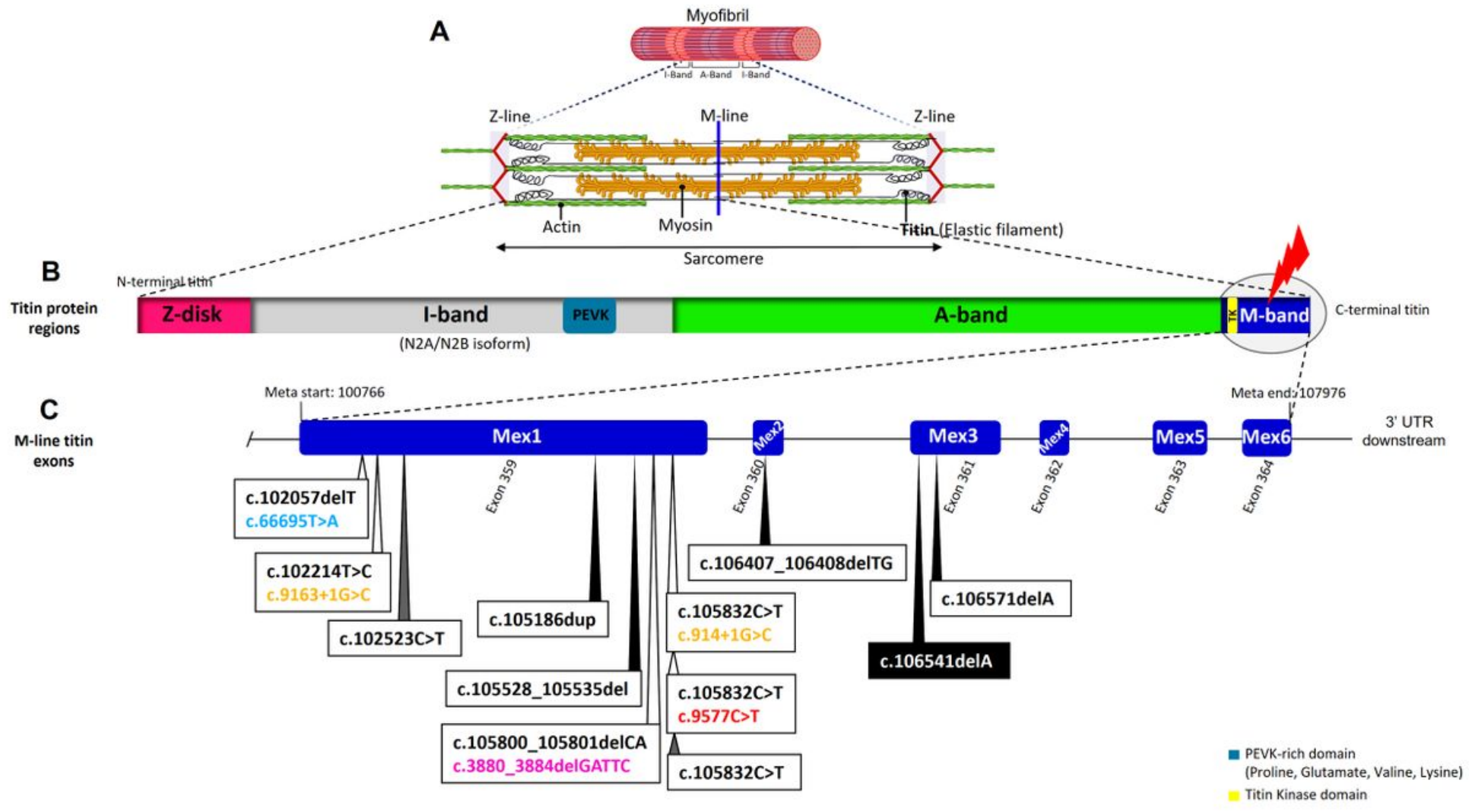

Figure 3

Titin regions and M-line TTN mutations reported in the literature in patients with congenital myopathy associated with heart disease. A Schematic view of the muscle fiber and sarcomere (prepared by BioRender). The spring segments represent titin protein extending from the Z-disc to M-band. B Schematic presentation of four titin protein regions. C The latest six exons of genomic titin region from Mex 1 to Mex 6 encoding the M-band region. Black triangles indicate homozygous mutations at M-line TTN. Grey triangles indicate TTN mutations detected at compound heterozygous state inside the M-line. White triangles indicate compound heterozygous mutations, which one located in the M-band and the second mutant allele outside it. Mutations located at the Mline titin exons are illustrated in black color. Mutations of the second allele outside the M-band are illustrated in the following manner: nonsense (in red), frameshift (in purple), missense (in blue), and splice site (in yellow). The black box refers to novel unpublished mutation identified in this study. 